\title{
USUCAPIÃO EXTRAJUDICIAL: VIABILIDADE E EFICÁCIA DA REGULARIZAÇÃO DO IMÓVEL
} USUCAPIENDO

\section{ADVERSE POSSESSION: FEASIBILITY AND EFFECTIVENESS OF REGULARIZING THE PROPERTY}

\author{
Frank Pavan de Souza ${ }^{1}$ \\ Bianca Gomes da Silva Muylaert Monteiro de Castro² \\ Luiz Victor Monteiro Alves ${ }^{3}$ \\ Ralph da Silva Barreto ${ }^{4}$
}

\section{RESUMO}

A usucapião extrajudicial apresenta-se como uma forma de aquisição originária da propriedade imóvel requerida diretamente no Registro de Imóveis. Sua importância é a aplicabilidade da regularização de imóveis pela via extrajudicial, haja vista a posse, por aqueles que a detêm, por lapso temporal suficientemente exigido pela lei em face da prescrição aquisitiva dos detentores de direitos reais registrados ou averbados na matrícula do imóvel usucapiendo. Por muito tempo, o procedimento da usucapião era tido como um dos mais dificultosos procedimentos especiais descritos pelo antigo Código de Processo Civil (1973). Hodiernamente, com o advento do Novo CPC (2015), há uma nova perspectiva para a regularização de imóveis. Esse procedimento extrajudicial é mais simples e mais rápido que uma ação de usucapião, eis que ações judiciais de usucapião costumam durar vários anos. O NCPC introduziu na Lei de Registro Público (LRP) o Art. 216-A viabilizando a aplicabilidade do

\footnotetext{
${ }^{1}$ Pós Doutor pelo Programa Interdisciplinar em Ciências Humanas (Meio Ambiente e Sociedade) da Universidade Federal de Santa Catarina (UFSC). Doutor em Engenharia Civil - Gestão de Recursos Hídricos e Saneamento pela COPPE/UFRJ. Professor da Universidade Cândido Mendes - UCAM Campos. Universidade Cândido Mendes UCAM Campos. Lattes: http://lattes.cnpq.br/2253512055632791 E-mail: frankpavan@gmail.com

2 Doutoranda no Programa de Pós Graduação em Sociologia Política da Universidade Estadual do Norte Fluminense (PPGSP/UENF). Mestre em Políticas Sociais pela Universidade Estadual do Norte Fluminense. Professora da Universidade Cândido Mendes - UCAM Campos. Universidade Estadual do Norte Fluminense. ORCID: https://orcid.org/0000-0001-5362-9476 Lattes: http://lattes.cnpq.br/9794074032406197 E-mail: biamonteirodecastro@hotmail.com

${ }^{3}$ Advogado. Professor da Universidade Cândido Mendes - UCAM Campos. Universidade Cândido Mendes - UCAM Campos. Lattes: http://lattes.cnpq.br/0460792961269258 E-mail: monteiroalves@hotmail.com

${ }^{4}$ Graduando em Direito na Universidade Cândido Mendes - UCAM Campos . Universidade Cândido Mendes UCAM Campos. E-mail: frankpavan@gmail.com
} 
procedimento extrajudicial. A Lei $\mathrm{n}^{\circ} 13.465 / 2017$ concedeu nova redação ao mencionado artigo. $\mathrm{E}$, posteriormente, o Conselho Nacional de Justiça (CNJ) trouxe diretrizes com o Provimento $n^{\circ} 65$, regulamentando o procedimento nos cartórios. O reconhecimento extrajudicial da usucapião torna-se uma das inovações mais importantes introduzidas no Direito Imobiliário e Registral Brasileiro, com a vigência do Novo Código de Processo Civil/2015. A metodologia teve por base pesquisas descritivas, bibliográficas e entrevistas. Neste sentido, o objetivo da pesquisa foi analisar a viabilidade e eficácia da regularização do imóvel usucapiendo por meio da usucapião extrajudicial. O método científico utilizado foi o hipotético dedutivo e a abordagem da pesquisa foi qualitativa, por meio de textos científicos, leis e conteúdos publicados em sites oficiais. Ao final, concluiu-se que a usucapião extrajudicial introduzida no ordenamento jurídico brasileiro é hábil a produzir efeitos práticos em prol do usucapiente.

Palavras Chave: Usucapião Extrajudicial. Provimento $n^{\circ} 65$ do CNJ. Regularização do Imóvel Usucapiendo.

\section{ABSTRACT}

The extrajudicial adverse possession appears as a form of acquisition originating from the immovable property required directly in the Real Estate Registry. Its importance is to demonstrate the viability of real estate regularization by extrajudicial means, given the possession, by those who hold it, for a time period sufficiently required by law in view of the acquisitive prescription of holders of real rights registered or registered in the registration of property in adverse possession. For a long time, the adverse possession was regarded as one of the most difficult special procedures described by the old Procedure Civil Code (1973). Currently, with the New Procedure Civil Code (NPCC) advent (2015), there is a new perspective for the real estate regularization. This out-of-court procedure is simpler and quicker than a lawsuit of adverse possession because awsuits of this usually last several years. The NPCC introduced in the Public Registry Law (PRL) the Art. 216-A, making the application of the extrajudicial procedure feasible. Law no 13.465 / 2017 granted a new wording to mentioned article. And, later, the National Council of Justice (CNJ) brought guidelines with Provision no 65, regulating the procedure in the notary offices. The extrajudicial recognition of adverse possession becomes one of the most important innovations introduced in the Real Estate and Registral Brazilian Law, with the validity of the New Procedure Civil Code / 2015. The methodology was based on descriptive, bibliographical, interviews. The scientific method used was the hypothetical deductive. The work presents as a result the viability of the Extrajudicial adverse possession, created as an alternative to 
reach the property next to the real estate registry. It is concluded that the adverse possession extrajudicial introduced in the Brazilian legal system is able to produce practical effects in favor of who acquired the property's right.

Keywords: Extrajudicial Adverse Possession. National Council of Justice Provision no 65. Regularization the adverse possession property.

\section{INTRODUÇÃO}

O instituto de Direito Civil Usucapião Extrajudicial consubstancia-se no fenômeno da desjudicialização do Poder Judiciário Brasileiro. É o mais novo procedimento já desjudicializado (MELO, 2016).

A desjudicialização visa incentivar a solução de conflitos por meio de procedimentos alternativos extrajudiciais, nos casos em que há consensualidade, desincentivando o ingresso de novos processos junto ao Poder Judiciário, permitindo que este seja desafogado e possa concentrar seus esforços em lides que não exijam maior intervenção do Estado.

A Carta Magna Cidadã de 1988, já previa em seu escopo essa possibilidade. Com a reforma do Poder Judiciário, mediante a Emenda Constitucional 45/2004, tornou-se mais evidente essa tendência no Estado Brasileiro(BRASIL, 1988).

Antes mesmo dessa possibilidade de promover o procedimento da usucapião nas serventias cartorárias, perante os Oficiais de Registros de Imóveis, Títulos e Documentos, já havia outros procedimentos desjudicializados. Cita-se, por exemplo, o inventário, o divórcio e a retificação de metragens advindos do fenômeno da desjudicialização. E, ainda, cumpre ressaltar, que outros procedimentos poderão ser desjudicializados em breve, por exemplo, a adjudicação compulsória (BRASIL, 2017).

A usucapião extrajudicial, objeto deste trabalho monográfico, surge com o Novo Código de Processo Civil de 2015. É aprimorado pela Lei $n^{\circ} 13.465 / 2017$ e uniformizado o seu procedimento, em todo território nacional através do Provimento $n^{\circ}$ 65, de 14 de dezembro de 2017, do Conselho Nacional de Justiça (CNJ) (BRASIL, 2017). 
O procedimento extrajudicial da usucapião traz como vantagem para os jurisdicionados e para a advocacia, hodiernamente, a celeridade e eficiência das serventias cartorárias e, consequentemente, o desafogamento do judiciário (NOBRE, 2018).

Isso reforça, ainda, a nova forma de atuação da Advocacia Extrajudicial, pois a representação dos requerentes por advogado é exigida na maioria dos procedimentos (MELO, 2016).

O instituto da usucapião tem sua origem no Direito Romano, disciplinado na lei das Doze Tábuas. A palavra usucapião, etimologicamente, vem do latim usucapio e pode ser traduzida como: aquisição pelo uso (ALVES, 2007).

No Brasil, o instituto da usucapião vem numa constante evolução legislativa, a fim de ser instrumento para a solução de dúvidas sobre a propriedade. Ao conceder àquele que detém a posse o direito de obter a propriedade, materializa-se os princípios constitucionais da garantia do direito à propriedade e o da função social da propriedade (MELO, 2016).

A usucapião está associada a ideia de renúncia presumida do proprietário tabular do imóvel. O direito de obter a propriedade pelo reconhecimento da usucapião extrajudicial torna-se viável a consolidação da posse exercida por aqueles que não são os legítimos proprietários. A maioria da população adquire um único imóvel durante sua vida inteira. Para muitos ter o imóvel próprio, ter o domínio é um momento importantíssimo (MACULAN, 2017.

A evolução sofrida pela lei, em decorrência dos estudos doutrinários e dos novos entendimentos jurisprudenciais, se deu, através do fenômeno da desjudicialização do poder Judiciário, que tem por objetivo desafogar o mesmo, como já mencionado. (NOBRE, 2018).

Sua importância consiste em dedicar à propriedade a quem detém a posse em razão da sua função social, a fim de obter a escritura pública e seu respectivo registro no competente cartório da circunscrição do imóvel usucapiendo de maneira célere e eficaz, é cumprir e fazer cumprir o princípio constitucional da razoável duração do processo, disciplinado no Art. $5^{\circ}$, inciso, LXXVIII da CRFB/88.

Saber que mora no que é seu, que o domínio do imóvel the pertence, é demonstrar a viabilidade e eficácia ao promover a aquisição originária da propriedade, através da posse, comprovando o lapso temporal exercido pelo possuidor, exigido pela lei, mediante o novel instituto usucapião extrajudicial (MELO, 2016).

Dedicar à propriedade àqueles que não detêm os quatro poderes inerentes, quais sejam: usar, gozar, dispor e reivindicar, mas somente o poder de usar e gozar, por um lapso temporal considerado 
significante pela lei, torna-se uma problemática em busca da regularização do imóvel usucapiendo. A regularização do imóvel usucapiendo significa prover a subsistência humana, promover a justiça social, sempre com obediência ao princípio da dignidade humana (BRASIL, 1988).

O procedimento de reconhecimento extrajudicial da usucapião é ato privativo de advogado, pois a lei assim exige. Ao invés de ser exclusivamente realizado pela via judicial, o legislador viabilizou o seu procedimento pela via extrajudicial.Tratar do direito à propriedade é falar de direito fundamental (NOBRE, 2017).

A regularização proporcionará ao requerente uma valorização significativa do seu imóvel. Por exemplo, um imóvel de valor aproximado de mercado de $\mathrm{R} \$ \mathbf{3 0 0 . 0 0 0 , 0 0}$ (trezentos mil reais), regularizado pela usucapião extrajudicial, obterá uma valorização média de $40 \%$. Essa valorização ocorrerá dentro do prazo médio de 120 dias, que é o prazo médio para a finalização do procedimento extrajudicial da usucapião. Aplicando-se o percentual médio de valorização, passará valer $\mathrm{R} \$$ 420.000,00, na qual, terá um ganho de $\mathrm{R} \$ 120.000,00$ (cento e vinte mil reais), obtendo como média de rentabilidade mensal $\mathrm{R} \$ 30.000,00$ (trinta mil reais).

A relevância para regularização do imóvel usucapiendo será de amplitude macro, eis a justificativa, pois, além do já demonstrado no parágrafo anterior, os entes públicos arrecadarão mais tributos, os cartórios terão suas receitas ainda mais elevadas e, a advocacia extrajudicial atuará em um nicho de mercado muito promissor.

Neste sentido, a pesquisa teve como objetivo analisar a aplicabilidade da usucapião extrajudicial, disposta em leis e atos normativos, bem como seus procedimentos processuais.

\section{METODOLOGIA}

Para a realização da pesquisa, adotou-se o método hipotético-dedutivo com abordagem é qualitativa, vez que o objetivo deste estudo é de cunho teórico explicativo. Foi realizada uma investigação sobre os novos dispositivos legais que disciplinam o tema, explicando como os mesmos podem ser aplicados extrajudicialmente.

A interpretação das leis e atos normativos partirá da situação de fato da posse, com a análise da possibilidade jurídica em dedicar a propriedade ao possuidor não proprietário, desde que preenchidos os requisitos legais. 
Para discorrer sobre o instituto da usucapião no aspecto material e para analisar o referido instituto no aspecto processual, além de pesquisa doutrinária, foram realizadas pesquisas em acervos bibliográficos sobre o assunto, em sites científico e oficiais.

\section{DIREITO MATERIAL DA USUCAPIÃO}

No Brasil, o instituto da usucapião vem sofrendo mudanças significativas em prol da sociedade, a fim de ser um instrumento para a solução de dúvidas sobre a propriedade, principalmente em razão do fenômeno da desjudicialização, instituto que tem por finalidade desafogar o Poder Judiciário e incentivar procedimentos em âmbito extrajudicial (BOCZAR, 2018).

A usucapião tem sua origem no Direito Romano, disciplinado na Lei das Dozes Tábuas. A referida lei, sistematizava o direito que era praticado versando sobre procedimentos judiciais, propriedade, direito público e privado, entre outros assuntos complementares (ALVES, 2007).

A usucapião era um direito exclusivo apenas para os cidadãos romanos. Sendo posteriormente reconhecido aos demais habitantes em Roma. A palavra usucapião, etimologicamente, tem sua origem no latim usucapio e pode ser traduzida como: aquisição pelo uso ou tomar pelo uso. A usucapião, que era requerida, somente pela via judicial, também poderá ser processada, em favor de quem exerce a posse de um imóvel de maneira mansa, pacífica e sem oposição, provando a sua utilização no tempo, pela via extrajudicial ou cartorária, com a mesma segurança jurídica e confiabilidade do Poder Judiciário, tendo como vantagem, ainda, a celeridade da via administrativa.

Discorrer sobre o direito material da usucapião é adequar às modalidades de procedimentos da usucapião a cada situação fática da posse exercida pelos requerentes. A posse e a propriedade são juridicamente institutos diferentes, pois tanto a posse quanto a propriedade, no ordenamento jurídico brasileiro, têm características peculiares (RIBEIRO, 2012).

A posse é um fato percebido na natureza, enquanto o domínio (propriedade) só é percebido no universo jurídico, é uma idéia aceita pela coletividade através da sua normatização. Com relação a posse, há duas teorias: A Teoria Subjetiva (de Savigny) e a Teoria Objetiva (de Ihering).

Para Savigny, a posse se configura quando houver a apreensão física da coisa (corpus) mais a intenção de dono (animus domini); Já Ihering diz que a posse se configura com a mera conduta de dono, basta ter consigo a coisa. 
A teoria adotada pelo Código Civil Brasileiro (CCB) é a Teoria Objetiva de Ihering, pois exige-se tão somente a conduta de proprietário. O Art. 1.196 (CCB) ratifica a Teoria Objetiva de Ihering, ao dispor que o possuidor é todo aquele que tem de fato o exercício, pleno ou não, de algum dos poderes inerentes à propriedade. Percebe-se que o legislador não conceituou a propriedade, mas sim, atribuiu poderes qualificando a posse. Cumpre ressaltar, que a propriedade é um direito fundamental expresso no caput do Art. $5^{\circ}$ da Constituição da República Federativa do Brasil de 1988 (CRFB/88).

A natureza jurídica da usucapião encontra convergência no sentido de ser aquisição originária da propriedade, pelo decurso do tempo, em que há prescrição aquisitiva por inércia dos detentores de direitos registrados ou averbados na matrícula/transcrição do imóvel usucapiendo. Há possibilidade de obter um efeito libertador sobre os tributos, vez que é uma aquisição originária, mas segue a regra do Propter Rem (a obrigação o segue, seja qual for o título), já que tributo é dever fundamental.

A prescrição e a usucapião têm fundamentos em comum, qual seja, o decurso prolongado do tempo. Tanto o Código Civil Brasileiro de 1916, quanto o Código Civil de 2002 adotaram a corrente dualista, uma vez que consagram a prescrição como meio extintivo de ações, regulada na Parte Geral (Arts. 189 a 206) e a usucapião como modo de aquisição da propriedade, inserida no Livro de Direito das Coisas (CHAVES, 2012).

O avanço do estudo para a elaboração desse trabalho monográfico só será possível partindo da premissa da normatização das espécies de usucapião. Como já mencionado, a posse é aparentemente percebida pela coletividade, já o domínio demanda de verificação. Aquele que detém a posse, tem a faculdade de usar e gozar/fruir o imóvel (RIBEIRO, 2012).

Nem toda posse gera o efeito da usucapião, pois a posse exercida pelo requerente da usucapião extrajudicial tem que ser uma posse ad usucapionem, que é aquela prolongada pelo tempo definido em lei e que dá ao seu titular a possibilidade de aquisição do domínio. É a que enseja o direito de propriedade. Ademais, precisa preencher requisitos legais, como o de ter o animus domini (intenção de ser dono), por exemplo, para que se configure.

Por outro lado, existe a posse ad interdicta, que não gera usucapião por ser posse precária. Seria a posse do inquilino, do comodatário. É aquela posse, na qual, a pessoa recebe a coisa alugada ou emprestada para morar gratuitamente. Há, ainda, o fâmulo da posse, trata-se de quem detém a posse, mas em nome de outrem, é o caso do caseiro. 
A propriedade é a faculdade de usar, gozar e dispor, podendo reavê-la de quem injustamente a possua ou detenha, conforme o disposto no caput do Art. 1.228 do CCB. O que caracteriza a propriedade, diferentemente da posse são os 04 (quatro) poderes inerentes a mesma, quais sejam: o uso, o gozo ou fruição, a disponibilidade e o poder de reivindicar de quem injustamente a detenha.

O uso (jus utendi) é a utilização do imóvel para o fim a que se destina, por exemplo: morar na casa, realizar atividade econômica. O gozo ou fruição (jus fruendi) é o poder de explorar a coisa com vantagem econômica, como por exemplo, auferir renda através de alugueres. A disponibilidade (jus abutendi) é a construção jurídica com o registro, é poder modificar, aumentar, diminuir, vender. E, reivindicar (rei vindicato) é o poder de autotutela (defesa da posse) em face de quem injustamente a detenha. Dessa forma, conclui-se que, para a caracterização da posse há dois poderes: usar e gozar o bem imóvel. Já a propriedade é o poder de usar, gozar, dispor e reivindicar o bem imóvel.

Observa-se que o Novo Código de Processo Civil (Lei n 13.105/2015), ratificou no artigo 1.071 (BRASIL, 2015), a possibilidade da aquisição originária da propriedade, diante da força probante da posse pelo decurso do lapso temporal, introduzindo no ordenamento jurídico brasileiro a possibilidade de reconhecimento de qualquer espécie de usucapião de bem imóvel pela via extrajudicial.

A Usucapião Extrajudicial está prevista no artigo 216-A da Lei de Registros Públicos, este incluído pelo Art. 1.071 da Lei $n^{\circ}$ 13.105/2015 (CPC 2015). Culminando, ainda, com o posicionamento do Conselho Nacional de Justiça (CNJ), na edição do Provimento 65 de 14 de dezembro de 2017, em prol do usucapiente em buscar a legalização (MOREIRA, 2016).

É necessário observar que para se valer do instituto da usucapião extrajudicial, além da observância dos princípios constitucionais, deve-se ater, também, para os princípios do direito imobiliário, preceituados na Lei $n^{\circ}$ 6.015/73 (Lei de Registros Públicos). O procedimento extrajudicial torna-se imprescindível a observância principiológica imobiliária para a concretização da aquisição da propriedade de maneira célere e eficaz.

O Direito Imobiliário e Registral Brasileiro deu um grande passo, com repercussões sociais e econômicas. Diante desse novo dogmatismo jurídico no âmbito do Direito Imobiliário e Registral Brasileiro com a materialização dos princípios tanto constitucionais quanto registral, resta provado à viabilidade da legalização do imóvel, mediante o instituto do Direito Civil Usucapião Extrajudicial. 0 que era complexo de se realizar pela via judicial tornou-se o instrumento mais eficaz a possibilitar a tranquilidade da família detentora do imóvel em que ali, vivem, cuidam dos seus filhos e laboram para o sustento de cada dia (AGHIARIAN, 2015). 
A usucapião tem por objeto não somente a propriedade, mas também outros direitos reais, como o usufruto, o uso, a habitação e a servidão. Nesse sentido, o Provimento $\mathrm{n}^{\circ} 65$ do Conselho Nacional de Justiça (CNJ), disciplina no seu Art. $2^{\circ}$, parágrafo $1^{\circ}$, que o procedimento de reconhecimento da usucapião extrajudicial poderá abranger a propriedade e demais direitos reais passíveis da usucapião.

O usucapiente adquire o seu domínio (disponibilidade), e assim, pode registrar o bem imóvel em seu nome no Ofício de Registro de Imóveis. O direito de obter à propriedade pelo reconhecimento da usucapião extrajudicial possibilitou a consolidação da posse exercida por aqueles que não são os legítimos proprietários.

\subsection{Pressuposto da usucapião}

O requerente/usucapiente ao pleitear o reconhecimento extrajudicial da usucapião deverá observar se a coisa é passível de usucapião. Se o bem é passível de prescrição aquisitiva, pois nem todos os bens imóveis podem ser usucapido, por exemplo, os bens públicos e os fora do comércio. Estes não se podem contar tempo prescricional para a aquisição do direito de usucapião. Cita-se como bens públicos uma sede de Prefeitura, uma Praça Pública, o Cristo Redentor. Estes não são passíveis de usucapião e estão fora do manto da prescrição aquisitiva (RIBEIRO, 2012).

O Código Civil de 2002 disciplina nos Arts. 197 e 198 os casos em que não correm a prescrição aquisitiva, quais sejam: Entre cônjuges na constância da sociedade conjugal, entre ascendentes e descendentes, durante o poder familiar, entre tutelados e seus tutores, entre curatelados e seus curadores, contra incapazes de que trata o Art. $3^{\circ}$ do CCB, entre os ausentes do País em serviço público da União, dos Estados ou dos Municípios e contra quem estiver em serviço militar em tempo de guerra.

Outro pressuposto da usucapião seria a própria posse em si. Para restar configurada, requer o animus domini (intenção de dono), e que a posse seja mansa, pacífica e contínua.

O tempo, também é um dos pressupostos da usucapião. Deve-se observar o lapso temporal exigido para que ocorra a prescrição aquisitiva. O tabelião fará a subsunção do fato à norma, adequando às modalidades de usucapião ao tempo de posse provada pelo requerente do imóvel usucapiendo. Esse tempo de posse pode ser somado ao tempo do seu antecessor (acessio possessiones). Por outro lado, há a sucessio possessiones, que via de regra é a sucessão hereditária. Essa poderá ou não gerar efeitos para usucapião. 
A prova do tempo poderá ser através do justo título. Este que também é um pressuposto visa transferir entre pessoas, sejam físicas ou jurídicas, o domínio e/ou posse, de bens imóveis. O justo título é qualquer documento legal acordado entre as partes com a finalidade de transferir o imóvel. Pode ser uma escritura pública, um instrumento particular de venda e compra ou simplesmente uma cessão de direitos hereditários.

Há ainda, como pressuposto da usucapião, a boa-fé. Esta significa dizer que o possuidor acredita piamente que a coisa é sua, ignorando os vícios ou obstáculos que impedem a aquisição do bem. A boa-fé, geralmente está intrinsecamente ligada ao justo título. Mesmo estando o requerente em situação irregular em relação à propriedade, acredita piamente que aquilo que ele já possui em mãos Ihe confere a qualidade de domínio. Por exemplo, se o requerente tiver um documento que não foi levado a registro, este documento é um justo título que confere a boa-fé, porque ao estar na posse do imóvel, consubstanciada nesse justo título, o requerente da usucapião ignora o vício de não ter feito o registro da escritura de venda e compra. Assim, ao estar tão convicto de que o imóvel é seu, caracteriza-se a boa-fé.

\subsection{Modalidades previstas no ordenamento jurídico brasileiro}

A tipificação legal das espécies/modalidades de usucapião no Brasil está disposta na Constituição da República Federativa (CRFB/88), no Código Civil Brasileiro/2002 (CCB), nas Leis Especiais e nos Atos e Provimentos Normativos do Poder Judiciário.

Há no ordenamento jurídico brasileiro cerca de 10 (dez) modalidades de usucapião. Cada qual deve ser observada pelo Oficial de Registro de Imóveis de acordo com a situação fática da posse exercida pelo requerente. As espécies legais de usucapião são: Extraordinária Comum, Extraordinária Habitacional, Ordinária Comum, Ordinária Habitacional, Especial Comum Rural, Especial Urbana, Especial Familiar, Especial Coletiva Urbana, Especial Indígena e a Especial Rural (GONÇALVES, 2015).

As espécies de usucapião mais comuns são às extraordinárias. Essas não precisam de justo título, tampouco precisam da comprovação da boa-fé. Não se trata de incentivo a má-fé, apenas reforça a estabilidade das situações definidas e da paz social. Essa modalidade funda-se na posse e no tempo. A Usucapião Extraordinária é uma situação de fato sustentada pela inércia do antigo proprietário não tentar recuperar, para si, a posse exercida pelo requerente da usucapião. Subdividese em extraordinária comum e habitacional. 
A Usucapião Extraordinária Comum está disposta no caput do Art. 1.238 CCB. O requerente tem que comprovar a sua posse exercida no prazo de 15 anos, no mínimo. 0 possuidor tem que ter a intenção de dono (animus domini). A posse tem que ser mansa, pacífica e contínua. O imóvel a ser usucapido por essa modalidade pode ser tanto urbano quanto rural. Não há nessa modalidade área limite. Essa modalidade é a única que possibilita ao usucapiente requerer sendo possuidor de outros imóveis.

A Usucapião Extraordinária Habitacional está disposta no parágrafo único do Art. 1.238 CCB. Nessa espécie há um reduzido tempo de posse de 15 (quinze) anos para apenas 10 (dez) anos. 0 possuidor também tem que ter a intenção de dono (animus domini). A posse tem que ser mansa, pacífica e contínua. O imóvel a ser usucapido pode ser urbano ou rural. No entanto, exige-se que o requerente tenha estabelecido sua moradia habitual ou nele realizado obras ou serviços de caráter produtivo. Não há estipulação legal de área limite. Deve ser provada tal situação fática. Não basta ter IPTU. Outros meios probatórios são exigidos, inclusive a habitação propriamente dita e não só o exercício da posse.

A Usucapião Ordinária também se subdivide em duas espécies: Ordinária Comum e a Habitacional. Para requerer a usucapião nessas modalidades, além dos requisitos da espécie extraordinária de usucapião, diferente apenas no lapso de tempo exigido de posse, exige-se, também, justo título e a boa-fé. Observa-se que a noção de justo título está estreitamente conectada com a de boa-fé. Como esta presume-se (iuris tantum), cabe a quem de direito contestá-la. Nos aluguéis, por exemplo, o possuidor tem um justo título mais não se pode dizer que exerce a posse de boa-fé, porque não tem a intenção de ser dono.

A natureza do título -contrato de locação- não permite ao possuidor exercer uma postura de dono do imóvel. Por isso que cabe a quem de direito contestar a boa-fé. As formas violentas e clandestinas da posse não suportam a existência de um justo título, logo não encontram solidez na boa-fé. A violência é uma excludente da própria boa-fé. As invasões, grilagens, por exemplo, não induzem boa-fé, porque essas formas violentas não possibilita a imissão na posse. A violência pode ser vis compulsiva ou absoluta quando existe agressão ou vis relativa quando existe ameaça. No entanto, elas podem convalescer, salvo a posse precária que não se convalesce, por exemplo, os alugueres, comodato e os arrendamentos.

A Usucapião Ordinária Comum está disposta no caput do Art. 1.242 CCB. O requerente tem que comprovar a sua posse exercida no prazo de 10 (dez) anos no mínimo, pois essa modalidade exige 
o justo título, a boa-fé e a intenção de dono. A posse tem que ser mansa, pacífica e contínua. O imóvel a ser usucapido por essa modalidade pode ser tanto urbano quanto rural. Não há limite de área.

A Usucapião Ordinária Habitacional está disciplinada no parágrafo único do Art. 1.242 CCB. Nessa espécie há um reduzido tempo de posse de 10 (dez) anos para apenas 05 (cinco) anos. 0 possuidor tem que ter a intenção de dono. A posse tem que ser mansa, pacífica e contínua. O imóvel a ser usucapido pode ser tanto urbano quanto rural e também não há área limite exigida por lei nessa modalidade. Exige-se o justo título e a boa-fé e, ainda, o possuidor tem que ter moradia habitual ou nele realizado obras ou serviços de caráter produtivo. Deve ser provada tal situação fática. Não basta ter IPTU. Outros meios probatórios são exigidos, inclusive a habitação propriamente dita e não só o exercício da posse.

As modalidades de Usucapião Especial são as mais diferentes das demais espécies. Encontramse em diversos diplomas legais do Direito Brasileiro, seja no Código Civil, na Constituição Federal ou em Leis Próprias. O possuidor não pode ser proprietário de outro imóvel, urbano ou rural. As espécies de usucapião especial subdividem-se em Especial Comum Rural, Especial Urbana, Especial Familiar, Especial Coletiva Urbana, Especial Indígena e a Especial Rural.

A espécie de Usucapião Especial Comum Rural está disciplinada no Art. 1.239 CCB e no Art. 191 da CRFB/88. Para ingressar com esse requerimento de usucapião há como exigência, ao possuidor, que ele prove sua posse por 05 (cinco) anos ininterruptos. A área rural não pode ser superior a 50 hectares, equivalente a 500.000 mil metros quadrados. O requerente tem que ter estabelecido a sua moradia e toda área rural tem que ser produtiva. Deve exercer a posse sem oposição, com a intenção de dono (animus domini) de forma mansa e pacífica.

A espécie de Usucapião Especial Urbana está disciplinada no Art. 1.240 CCB. O possuidor tem que ter a posse por 05 (cinco) anos ininterruptos de área urbana não superior a 250 metros quadrados. Deve-se estabelecer sua moradia ou de sua família, sem oposição, com a intenção de dono, de maneira mansa e pacífica.

A espécie de Usucapião Especial Familiar está disposta no Art. 1.240-A do CCB. Ocorre em face do ex-cônjuge que abandona sua moradia e, consequentemente, sua família. O cônjuge que permanece no imóvel e com a família passa a ter, sozinho o domínio com exclusividade, não sendo mais a posse repartida com o ex-cônjuge que abandona a moradia do casal. Essa espécie torna-se uma garantia àquele cônjuge que permanece no ambiente familiar, para obtenção do domínio desse imóvel que o ex-cônjuge resolveu não mais ter a posse ou mantê-la, porque simplesmente abandonou a sua 
família e, por sua vez, a posse do imóvel. Essa espécie de usucapião familiar tem como requisito, exigido por lei para o seu requerimento, que o imóvel seja urbano, com área até 250 metros quadrados e 02 (dois) anos ininterruptos na posse do imóvel, sem oposição, de forma mansa, pacífica e o requerente não ser proprietário de outro imóvel rural ou urbano.

A espécie de Usucapião Especial Coletiva Urbana é regida pelo Art. 10 da Lei n 10.257/2001 (Estatuto da Cidade), que foi recentemente alterado pela Lei $n^{\circ} 13.465 / 2017$. No texto original, exigiase área urbana com mais de 250 metros quadrados, ocupada por população de baixa renda de forma coletiva para sua moradia por mais de 05 (cinco) anos ininterruptamente, sem oposição, onde não for possível identificar os terrenos ocupados por cada possuidor, não sendo os possuidores proprietários de outros imóveis rural ou urbano. O legislador entendeu por bem alterar diversos termos empregados na redação anterior ao aprovar a Lei $n^{\circ} 13.465 / 2017$. Essa lei trouxe as seguintes exigências com a nova redação do Art. 10 do Estatuto da Cidade: Núcleos informais urbanos ocupados há mais de 05 (cinco) anos, admitidos a continuidade, sem oposição. Sendo a área total dividida pelo número de possuidores, obtendo a área inferior a 250 metros quadrados como requisito. Os possuidores não podem ser proprietários de outro imóvel rural ou urbano.

A espécie de Usucapião Especial Indígena é regida pelo Art. 33 da Lei $n^{\circ}$ 6.001/1973 (Estatuto do Índio). Tanto o índio que já se integrou à sociedade como àquele que ainda não teve contato com outra cultura são amparados. Nessa espécie de usucapião frisa-se que o índio não vai usucapir terras indígenas, mas sim terras que são particulares. De acordo com o parágrafo único do Art. 33 é vedado usucapir terras públicas, mesmo sendo índios. Essa modalidade não exige justo título e boa-fé. O prazo da posse é de 10 (dez) anos. 0 requerente tem que ser o índio integrado à sociedade, porque se não for integrado, somente a Fundação Nacional do Índio (FUNAI) pode representá-lo.

A espécie de Usucapião Especial Rural pode ser requerida quando a área limite for de até 25 hectares. Está disposta no Art. $1^{\circ}$ da Lei $n^{\circ}$ 6.969/1981. O prazo de posse para obter o direito de requerer essa modalidade é de 05 (cinco) anos ininterruptos. Não há necessidade de justo título e boafé. A posse tem que ser mansa, pacífica e contínua. O imóvel necessariamente deverá ser rural, destinando-o como moradia ou de caráter produtivo. Os possuidores não podem ser proprietário de outros imóveis rural ou urbano. 


\section{DIREITO PROCESSUAL DA USUCAPIÃO}

Discorrer sobre o direito processual da usucapião extrajudicial é adequar o caso concreto ao processo e às exigências da lei a fim de que o requerente possa evitar às famigeradas notas devolutivas e não ocasionar atrasos nos trâmites processuais dentro do cartório de registro de imóvel (MELO, 2016).

A Usucapião Extrajudicial é a possibilidade de se processar no registro de imóveis o reconhecimento da usucapião sobre um determinado bem imóvel, desde que atendidas às exigências legais de ordem processual, além de todos os requisitos materiais abordados no capítulo anterior (NOBRE, 2018).

O direito processual da usucapião tem como base legal o Art. 1.071 da Lei $n^{\circ}$ 13.105/2015 (Novo Código de Processo Civil), pois este artigo introduziu na Lei $n^{\circ}$ 6.015/1973 (Lei de Registros Públicos), o Art. 216-A. A Lei n 13.465/2017 fez alterações positivas no Art. 216-A da LRP. Ademais, os Códigos de Normas das Corregedorias de Justiça dos Estados e o Provimento 65 do Conselho Nacional de Justiça (CNJ), deverão ser observados.

O pedido de reconhecimento extrajudicial é ato privativo de advogado e será requerido no competente Registro de Imóvel da circunscrição do imóvel usucapiendo. Ao buscar a regularização do imóvel usucapiendo, o requerente deverá contratar um advogado ou ser assistido pela defensoria pública. Nesse sentido, percebe-se que a advocacia extrajudicial é uma tendência inovadora para soluções jurídicas, muito mais céleres do que a propositura de ações na justiça, tendo em vista a ausência de litígios.

A Advocacia Extrajudicial consubstancia na desjudicialização e torna-se uma prestação extrajudicial viável e eficaz na regularização do imóvel usucapiendo. Inclusive com sua eficiência procedimental comprovada em outros institutos do direito civil já desjudicializados no Brasil, como por exemplo, os inventários, os divórcios consensuais e a retificação de metragem.

\subsection{Requisitos indispensáveis ao procedimento}

Para o requerimento da usucapião extrajudicial, o advogado deve ater-se aos requisitos indispensáveis ao procedimento extrajudicial da usucapião, quais sejam: Petição de Reconhecimento Extrajudicial assinada por Advogado e acompanhada de procuração; Ata Notarial lavrada em Cartório 
de Notas; Planta e Memorial Descritivo; Anuência dos Detentores de Direitos Averbados ou Registrados na matrícula do imóvel e dos confrontantes; Certidões Negativas dos Distribuidores e dependendo da espécie de usucapião requerida, o justo título ou qualquer documento que corrobore com a posse. Ademais, o procedimento de registro da Usucapião Extrajudicial no Ofício de Registro de Imóveis deve observar os Princípios Jurídicos que regem o Registro de Imóveis.

A Petição de Reconhecimento Extrajudicial da Usucapião deve ser acompanhada por procuração que concederá poderes ao patrono para todos os atos extrajudiciais de reconhecimento da usucapião. A Base Legal desse requisito encontra-se no caput do Art. 216-A da Lei n 6.015/73. Cumpre ressaltar que o Oficial Público não faz o requerimento de ofício, pois o Art. 13 inciso II da Lei de Registros Públicos consagra o Princípio da Reserva de Iniciativa, já que os atos do registro serão praticados a requerimento verbal ou escrito pelos interessados.

O requerimento verbal mesmo estando previsto no inciso II do Art. 13 da LRP, dificilmente será admitido, visto que o Oficial de Registro deve zelar pelo Princípio da Fé Pública ou Legitimação Registral. O Tabelião buscará a segurança jurídica como forma de garantir a fé pública que detém e a sua legitimação registral, logo, ele dificilmente admitirá um pedido verbal de registro, pois não terá como provar que atendeu o princípio da reserva de iniciativa.

Dessa forma, o Oficial de Registro Público, para garantir a segurança jurídica e eficácia dos atos de averbações e registro praticados, requererá que a solicitação seja por escrito e com firma reconhecida. Como já mencionado, o requerente deverá ser representado por advogado e a petição conterá dados importantes para o registro da usucapião extrajudicial, inclusive deve estar acompanhada de procuração.

A Ata Notarial lavrada em Cartório de Notas tem por objetivo instruir a Petição de Reconhecimento Extrajudicial da Usucapião. Sua base legal encontra-se no Art. 216-A, inciso I da LRP, na Lei $n^{\circ}$ 8.935/1994 (Lei dos Cartórios) nos Arts. $6^{\circ}$ inciso III e 7º III, e na Lei n 13.105/15 (NCPC) no Art. 384 e no Art. 215 CCB. Trata-se de um instrumento lavrado pelo Tabelião ou seu preposto autorizado, onde ele transcreve fatos que por ele tenham sido verificados, dando a estes os atributos da publicidade e da fé pública, tudo isso a requerimento da parte interessada.

A Ata Notarial lavrada pelo Tabelião, atesta o tempo de posse do requerente e seus antecessores, conforme o caso e suas circunstâncias, serve para pré-constituir prova dos fatos apresentados ao Tabelião. É como se o Tabelião fosse uma testemunha com fé pública, constituindo prova perante terceiros. A Ata Notarial concede à situação fática o peso da fé pública. 
Para a lavratura da Ata Notarial não há exigência legal da presença do advogado. Todavia, este representando o seu cliente, pode requerer a sua lavratura e apresentar os fatos que se quer constituir prova. Como a posse não é uma situação de direito, mas sim, uma situação fática, precisa ser provada de forma pública, pois demonstrará aquilo que se alega, erga omnes.

A Planta e o Memorial Descritivo descreve as características do imóvel usucapiendo. Está disposta no Art. 216-A, II da LRP. Não basta somente a Planta ou o Memorial Descritivo, ambas deverão ser providenciadas pelo requerente. A Planta trata-se de um projeto de cunho arquitetônico do imóvel, define o seu funcionamento, seu tamanho e, havendo no imóvel edificação, descreve quantidade, disposição de cômodos e outros detalhes como circulação e iluminação.

O Memorial Descritivo é um documento que transcreve os elementos da Planta, contém todas às informações possíveis sobre o imóvel de forma extremamente detalhada como a descrição do imóvel, medidas perimetrais, área total, localização, confrontantes e coordenadas georeferenciadas dos vértices definidores dos seus limites. A Lei n 6.496/1977 estabelece que todos os contratos de execução de serviços ou obras deverão ser realizados por profissionais inscritos no Conselho Regional de Engenharia e Agronomia - CREA, com a respectiva Anotação de responsabilidade Técnica (ART).

A Anuência do Detentor de Direitos Averbados ou Registros na matrícula do imóvel e dos confinantes tem sua fundamentação legal no Art. 216-A, II, in fine, da LRP. Essa anuência vem corroborar o caráter conciliatório extrajudicial. O Oficial de Registro de Imóveis não tem como função julgar, função esta exclusiva do judiciário. Caso a anuência seja efetivamente negada, o procedimento extrajudicial será remetido para o judiciário, sendo oportunizado às devidas adequações na petição inicial (BRASIL, 1973).

A Lei $n^{\circ} 13.465 / 17$ disciplina que o silêncio dos detentores de direitos registrados ou averbados na matrícula do imóvel induz anuência. Não é qualquer pessoa que poderá dar anuência, mas todo aquele que for titular de direitos registrados ou averbados na matrícula do imóvel usucapiendo. Aqui cabe mencionar o que é Registro e Averbação (BRASIL, 2015).

O Registro está disposto no Art. 221 da LRP, e é o ato cartorário que declara quem é o proprietário formal e legal do imóvel e, ainda, se a propriedade está sendo transmitida. Já a Averbação que está disposta no Art. 246 da LRP é o ato que anota todas as alterações ou acréscimos referentes ao imóvel ou às pessoas que constam do registro. Pode-se citar como titular de direitos o proprietário, o promissário comprador, bancos/instituição financeira titular de alienação fiduciária ou hipoteca, indisponibilidade de bens, entre outros. 
As Certidões Negativas dos Distribuidores têm sua fundamentação legal para o procedimento extrajudicial da usucapião, no inciso III do Art. 216-A da LRP. Visam certificar se existem ações judiciais distribuídas em nome do requerente. O cartório distribuidor certificará mediante emissão de certidões, se o requerente da usucapião não está respondendo alguma constrição judicial que o impeça de usucapir o imóvel pela via extrajudicial (NOBRE, 2018).

Cumpre ressaltar que o pedido de certidões, sejam elas cíveis, criminais, de execução fiscal, cível para escritura pública e outras, não são em nome do titular de direitos registrados ou averbados na matrícula/transcrição, e sim em nome do requerente da usucapião. Isso porque desde fevereiro de 2017 entrou em vigor a regulamentação do princípio da concentração da matrícula, através da Lei $n^{\circ}$ 13.097/2015. Todas as informações quanto a feitos ajuizados, referentes ao imóvel e seu proprietário, devem estar averbados ou registrados na matrícula do imóvel. Esse princípio simplificou o procedimento, pois basta a certidão do registro de imóveis para se verificar tudo acerca do imóvel e das pessoas detentoras de direitos reais averbados ou registrados na matrícula/transcrição.

O Art. 216-A, IV da LRP, disciplina sobre o justo título e outros documentos que demonstram a posse. $\mathrm{O}$ justo título visa transferir entre pessoas físicas ou jurídicas, domínio e/ou posse de bens imóveis. Cita-se o sinal de compra e pagamento de lote, a promessa de venda e compra, a cessão de direito de posse.

O requerente poderá valer-se de outros documentos que demonstram a origem, a continuidade, a natureza e o tempo de posse. Percebe-se que o próprio inciso IV já sugere exemplos desses documentos, como pagamentos de impostos e taxas. Caso o requerente não tenha o justo título ou os documentos sejam insuficientes, a posse poderá ser comprovada em Procedimento de Justificação Administrativa, obedecendo, no que couber, ao disposto no parágrafo 15 do Art. 216-A da LRP, ao disposto no parágrafo $5^{\circ}$ do Art. 381, e ao rito previsto nos Arts. 382 e 383 do CPC/15.

O procedimento de reconhecimento extrajudicial da usucapião é uma solução viável para a regularização de imóveis por quem é apenas posseiro. Além da observância dos requisitos ora explicitados, o requerente obterá êxito respeitando os princípios do Direito Imobiliário e Registral. Aqui é que vai fazer a diferença entre o advogado estudioso, especialista no assunto, daquele que não conhece os Princípios do Direito Imobiliário. 


\subsection{Princípios do direito imobiliário e registral}

O advogado que não conhecer esses princípios elaborará sua petição que certamente cairá em exigências processuais, na qual poderá provocar atrasos na regularização do imóvel com formulação das notas devolutivas emitidas pelo Tabelião. A observância destes princípios evitará a maioria das notas devolutivas. Os princípios do Direito Imobiliário e Registral são: Legalidade, Fé-Pública ou Legitimação Registral, Publicidade, Obrigatoriedade, Territorialidade, Prioridade e Preferência, Reserva de Iniciativa, Tipicidade, Especialidade Objetiva, Especialidade Subjetiva, Continuidade, Disponibilidade, Unitariedade e Concentração da Matrícula (SARMENTO FILHO, 2017).

Todos são importantes, no entanto, serão analisados aqueles que estão intrinsecamente ligados ao processo de reconhecimento da usucapião nos cartórios. O sucesso ao dedicar a propriedade àqueles que detém a posse consubstancia-se nos princípios em destaque. Serão abordados aqueles inerentes ao Direito Registral. O advogado terá que atentar para esses princípios de maneira precisa em sua petição, pois do contrário cairá em exigências nos trâmites processuais na serventia cartorária.

O Princípio da Prioridade e Preferência significa dizer que o primeiro a apresentar seu título/requerimento tem a prioridade perante terceiros do próprio direito requerido, assim como terá preferência na ordem de efetivação do registro. Sua base legal encontra-se nos Arts. 12 e 186 da LRP. Torna-se proprietário comprador quem registrar primeiro o seu título. Ocorre no dia-a-dia de um imóvel ser vendido duas vezes através de escritura pública. Para valer esse princípio, existe o sistema da prenotação que gera um número de ordem, devidamente registrado no Livro 1 do Registro de Imóveis, que é o livro que registra o número de ordem de entrada no cartório.

O Princípio da Reserva de Iniciativa está disposto nos Arts 213, 217 e 246 da LRP, diz que a iniciativa da prática de atos de averbação e registro cabe exclusivamente ao interessado. Daí a necessidade de requerimento/petição, devendo todos os atos que se pretende praticar serem devidamente especificados. Não basta realizar um pedido genérico, tem que ser um requerimento específico para cada ato de averbação ou registro. A exceção a essa regra está disposta no Art. 213, I da LRP.

O Princípio da Tipicidade tem como base legal os Arts. 167 e 172 da LRP. Esses artigos elencam todos os atos de registros e averbação. Somente podem ser registrados os títulos que tenham previsão legal. É por este motivo de a cessão de posse não ser registrável. 
O Princípio da Especialidade Objetiva está disposto nos Arts. 176, parágrafo 1º, II, item 3, 222 e 225, parágrafo $2^{\circ}$, da LRP. Os documentos apresentados para averbação ou registro devem conter a plena e perfeita descrição do imóvel, assim como consta no registro anterior. Se às informações do título estão desencontradas em relação ao que consta na matrícula, no que diz respeito às características do imóvel, o título ficará impedido de ser registrado.

O Princípio da Especialidade Subjetiva está disciplinado no Art. 176, parágrafo $1^{\circ}$, II, item 4 da LRP. Os documentos apresentados para averbação ou registro devem conter a plena e perfeita identificação das pessoas nomeadas, assim como consta no registro anterior. Se as informações do título estão desencontradas em relação ao que consta na matrícula, no que diz respeito à identificação e qualificação das pessoas, o título ficará impedido de ser registrado.

O Princípio da Continuidade tem como base legal os Arts. 195, 222 e 237 da LRP. Esse princípio diz que todos os atos no assento registral imobiliário devem ser lançados de forma contínua e sucessiva. A ordem cronológica e dominial não pode ser desrespeitada jamais. A ordem dominial engloba todos os fatos jurídicos constitutivos, modificativos, translativos ou extintivos de direitos sobre o imóvel.

O Princípio da Disponibilidade está disposto nos Arts. 176, 195 e 227 da LRP. A importância desse princípio para a usucapião encontra-se no sentido de não haver qualquer questão de constrição no imóvel, pois esta inviabilizará o procedimento extrajudicial. Esse princípio visa garantir que ninguém possa transferir mais direitos do que possui averbados ou registrados no assento registral imobiliário. A disponibilidade compreende tanto as disponibilidades físicas (área disponível do imóvel) quanto a jurídica (situação jurídica do imóvel e da pessoa).

O Princípio da Concentração da Matrícula tem como base legal os Arts. 54, 55, 56 e 59 da Lei $n^{\circ}$ 13.097/2015. Antes, porém já havia previsão legal na Lei de Registros Públicos nos Arts. 167, II, 5 c/c 246 parágrafo $1^{\circ}$. Esse princípio é o mais recente do Direito Registral. Significa que todas as informações e direitos que tenham influência no registro imobiliário, da qual terceiros deveriam ter conhecimento, deverão estar averbados ou registrados no assento registral (matrícula/transcrição), sob pena de tal situação não ser oponível a terceiros de boa-fé, inclusive sobre a hipótese de evicção, pois não atingirá o imóvel.

Esse princípio trouxe como exigência que todas às ações na justiça referente ao imóvel têm que está averbadas ou registradas na matrícula/transcrição do imóvel, pois se não estiver, aquele que solicitar uma certidão deste imóvel e na certidão não constar às averbações dessas informações, não 
serão necessárias obter as certidões dos distribuidores, referentes a pessoa que está na matrícula como proprietário ou como detentor de algum outro direito, bem como, em relação ao imóvel, não serão necessárias às certidões dos distribuidores.

Portanto, devem ser averbados/registrados na matrícula/transcrição todas as ocorrências que alterem o registro, inclusive títulos de natureza judicial ou administrativa, para que haja a publicidade ampla e de conhecimento de todos, preservando e garantindo os interesses de adquirentes/terceiros. Por isso, esse princípio é muito importante, porque se não houver a comunicação no registro de imóveis sobre a constrição, perde-se o direito de se opor em relação a uma futura transmissão desse imóvel. Assim, as informações constantes dos registros ou averbações são suficientes para atestar tanto a titularidade dos direitos quanto às restrições pessoais e os ônus, encargos ou gravames existentes no imóvel.

\section{REGISTRO GERAL DE IMÓVEIS E A USUCAPIÃO}

\subsection{Tramitação de um processo no registro de imóveis}

Os serviços notariais e de registro são exercidos em caráter privado, por delegação do Poder Público. No interior dos Registros de Imóveis há diversos setores, tais como: A recepção, prenotação, arquivo e certidão, exame e registro, e o protocolo (SERRA, 2018).

Cada cartório tem suas particularidades setoriais. Existem cartórios que são considerados pequenos e por esse motivo não são divididos por setores. Como exemplo, cita-se os Ofícios Únicos existentes em alguns municípios, aqueles que não estão nas regiões metropolitanas, mas sim, nas regiões do interior do Brasil.

Na Recepção, o requerente elaborará o orçamento do título a ser averbado/registrado e emitir boleto para pagamento dos emolumentos. Após o pagamento o interessado retorna a este setor e da entrada no processo de registro.

Depois que o processo já foi recepcionado, será encaminhado para o setor da Prenotação, para que seja verificado a regularização do mesmo. Todos os atos que serão praticados e cada título/requerimento é prenotado com um número de ordem. 
Para garantir essa ordem de prioridade, o mais correto é que o título seja prenotado já na recepção, mas, principalmente, em cartórios de maior porte, esse setor faz uma revisão deste trabalho, a fim de orientar o examinador jurídico para que este possa elaborar uma exigência, se necessário.

O Arquivo e Certidão é o setor que procederá com todas as buscas nos acervos registrais. Separa a ficha da matrícula do imóvel e entrega ao examinador jurídico, a fim de levantar constrições. Por exemplo, se houver uma indisponibilidade de bens deve ser levantada nessa fase processual. Todas as informações devem ser devidamente levantadas.

No Setor de Exame e Registro serão realizados os exames de qualificação do título. Verifica-se o título/requerimento e se os documentos arrolados atendem os princípios jurídicos e às exigências legais.

Se houver exigências, o examinador elabora notas devolutivas fundamentadas e encaminha o processo à recepção para ciência do requerente. Este cumpre às exigências e toda a tramitação é repetida até aqui. Assim, demonstra-se a importância do advogado em evitar possíveis exigências, realizando análise prévia do caso concreto.

Ao evitar às exigências, o processo seguirá o seu curso normal. Dessa forma, o examinador encaminhará o processo para o Registrador. O setor marca um prazo para registro (término do processo). Em seguida, o Registrador termina sua tarefa e encaminha o processo de registro para o protocolo.

No Setor de Protocolo serão separados os documentos que ficarão arquivados e os que serão devolvidos ao requerente. Todo o processo até aqui é conferido, principalmente questão dos emolumentos, para conferir se tudo foi devidamente recolhido.

Verifica-se que o processo vai passando por vários filtros. Todos os setores que sucedem o anterior fazem uma verificação do processo, pois um setor fiscaliza o que o outro faz. A segurança jurídica dos atos praticados nos cartórios advém dessa dinâmica (BORGES, 2014).

O Protocolo é o fiscalizador final, esse setor vai conferir todo processo e saber se tudo foi feito de acordo com o que determina a legislação. Os documentos a serem devolvidos recebem os selos (um para cada ato prenotado). A ficha do imóvel, os selos e suas etiquetas são encaminhados ao Oficial de Registro para assinaturas. 
Por fim, os documentos a serem devolvidos, já protocolados, são encaminhados à recepção para ficarem a disposição do requerente. Neste ponto, já temos os atos requeridos devidamente registrados e uma nova certidão do imóvel já estará atualizada.

Após essa abordagem prática dos procedimentos dentro dos cartórios que tem por finalidade demonstrar a dinâmica interna no Registro Geral de Imóveis, verifica-se que o pedido de reconhecimento extrajudicial da usucapião seguirá as mesmas regras procedimentais.

A usucapião extrajudicial seria a porta dos fundos do sistema registral. Dessa forma, a usucapião extrajudicial surgiu com a finalidade de ingressar com o título no Registro de Imóveis nos casos em que não há possibilidade de obter a propriedade.

Ao final da década de 1980, empreendimentos formados por casas eram comercializados no modelo de loteamentos. Nem todos os loteamentos comercializados nesse período eram regularizados.

Muitos eram sítios ou propriedades rurais oriundos de herança, inventários que não andavam e até mesmo por problemas cadastrais junto à prefeitura. Esses imóveis eram vendidos de forma irregular, através de: Promessas de Compra e Venda vinculados a término de inventário, regularização junto a prefeitura, desmembramento da área junto ao Registro de Imóveis (DINIZ, 2009).

Outros títulos como: Cessão de Direitos de Posse, Cessão de Direitos Hereditários de Fração de Terreno, os Contratos Particulares de Compra e Venda, por exemplo, não pode ser levados a registro, porque não há previsão expressa na Lei de Registros Públicos, como sendo títulos hábeis a serem registrados. No entanto, esses títulos são importantíssimos para o requerente, porque é justo título, que servem para provar o tempo de posse (MELO, 2016).

Esses imóveis sem regularização, deu origem ao que hoje são bairros inteiros. Lotes que possuem IPTU, mas estão irregulares na Prefeitura e no Registro Geral de Imóveis (RGI). Muitos posseiros não conseguem regularizar, porque são impedidos pelos entraves administrativos, jurídicos e o tempo decorridos gerou ainda mais exigências.

Considerada parcela desses imóveis foram adquiridos por boa-fé, alguns possuindo justo título. Desta feita, os adquirentes intentam regularizar suas propriedades, tendo em vista a valorização monetária que esses imóveis podem vir a sofrer, o que de certo modo melhora as condições de uma futura negociação. 
Além de aumentar o valor de venda do seu imóvel, o requerente interessado em regularizar pela usucapião extrajudicial, poderá oferecer o imóvel como garantia de empréstimos, poderá aceitar Carta de Crédito ou financiamento para vender, ou outros benefícios que a regularização trará, tais como, não deixar um problema para sucessores, valorização do imóvel em havendo a volta do aquecimento do Mercado Imobiliário ou simplesmente alugá-lo para fins comerciais.

Conclui-se que há um grande nicho de mercado imobiliário envolvendo a Usucapião Extrajudicial, que é a regularização de loteamentos irregulares, porém, não é a única hipótese viável. A regularização de imóvel através da usucapião extrajudicial resolve o problema mais grave de um imóvel: O possuidor não ser o legítimo proprietário.

O Advogado para ter sucesso é importante que conheça a parte material da usucapião, a parte processual extrajudicial, o Direito Notarial e Registral Imobiliário. Poucos possuem este conhecimento. A maioria dos advogados não tem experiência junto aos Cartórios, alguns até possuem conhecimento teórico, mas não é suficiente. É necessário para obter sucesso no pedido extrajudicial da usucapião adquirir não somente o conhecimento teórico, mas também o prático, dominando-o em pouco tempo.

O advogado poderá resolver aqueles problemas de maneira muito mais célere na via extrajudicial, tanto que alavancará os seus ganhos, pois prestará um serviço de qualidade com a mesma segurança jurídica do Poder Judiciário, num prazo médio de 120 dias.

A usucapião extrajudicial resolve um problema que era da usucapião judicial: A demora que era em média de 15 (quinze) anos, na via judicial, reduziu-se em média para um curto lapso temporal de aproximadamente 04 (quatro) meses, em média.

Cada Estado da Federação tem o seu provimento disciplinando o procedimento extrajudicial da usucapião. Todavia, o Provimento 65 do CNJ foi editado com o fim de uniformizar o procedimento em âmbito nacional, devendo, para tanto, todos os Estados da Federação adequar os seus provimentos ao de amplitude em todo território brasileiro, qual seja, o Provimento 65 do CNJ.

Segundo o disposto no Art. $9^{\circ}$ do Provimento 65 do CNJ, o requerimento, juntamente com todos os documentos que o instruírem, será autuado pelo oficial do registro de imóveis competente, prorrogando-se os efeitos da prenotação até o acolhimento ou rejeição do pedido. Isso significa dizer que a usucapião tem um privilégio maior do que os demais títulos que ingressam no cartório, pois a regra geral é de 30 (trinta) dias para providenciar possíveis exigências, sob pena de os requerimentos serem extintos, conforme o disposto no Art. 188 da Lei $n^{\circ}$ 6.015/1973. 


\subsection{Etapas da tramitação da usucapião extrajudicial}

Como já mencionado, os processos comuns têm um prazo de validade de prenotação de 30 (trinta) dias. Significa dizer que entrando em exigência, o interessado em manter aquele número de ordem, em manter aquela prenotação tem que cumprir às exigências em 30 dias.

A usucapião extrajudicial tem um prazo diferente, pois ao ser autuado pelo Oficial ou seu substituto legal, terá seus efeitos prorrogados até o acolhimento ou rejeição do pedido.

Cumpre ressaltar, que o Cartório de Registro de Imóveis presta serviços à sociedade, em caráter privado, por delegação do Poder Público, segundo o disposto no Art. 236 da CRFB/88. Dessa forma, os cartórios têm uma característica sui gêneris, porque é uma mescla entre o serviço público e o particular.

O Registro de Imóveis é composto por diversos livros que estão dispostos no Art. 173 da LRP.

O Livro 1 - chamado de Protocolo é o primeiro livro do cartório, na qual, são registrados todos os protocolos, resguardando o número de ordem dos processos, e a ordem de todos os documentos que entram no cartório.

O Livro 2 - Registro Geral encontra-se o lançamento das matrículas dos imóveis e os atos de registro que são lançados na matrícula. Todas as matrículas estão transcritas no Livro 2, que é autorizado por lei a funcionar no sistema de fichas e não folhas. Cada número de matrícula representa uma ficha imobiliária de um determinado imóvel.

O Livro 3 - Registro Auxiliar - Todos os registros que auxiliam às informações contidas no Registro Geral são lançados nesse livro. Por exemplo, cita-se às escrituras públicas de pacto antenupcial. Esse registro faz comunicação na matrícula do imóvel.

O Livro 4 - Indicador Real - Toda vez que houver um ato registrado na matrícula do imóvel que altere as questões referentes as características do mesmo, deve-se promover uma comunicação do registro na matrícula com o indicador real.

O Livro 5 - Indicador Pessoal - Toda vez que um ato de registro ou averbação é procedido na matrícula do imóvel, que apresenta novos personagens no assento registral imobiliário, que traz novos nomes no assento registral ou que há transmissão, é indicado também nesse livro, essa transferência de ordem pessoal e as constrições também de ordem pessoal, são lançadas nesse livro com a finalidade de facilitar às buscas do imóvel. 
Nos Livros 4 e 5 são realizadas buscas para verificar se o imóvel tem ou não registro e se aquelas constantes na matrícula são ou não os atuais proprietários. Dessa forma, caso o imóvel não tenha sido registrado ou ninguém nunca o registrou, poderá o possuidor usucapir para obter sua aquisição originária com a consequente abertura de matrícula.

O procedimento extrajudicial da usucapião será submetido a um exame. Serão feitas verificações das anuências na planta e memorial descritivo. Constatando-se que às anuências já estão na planta e no memorial descritivo, seguirá para ciência da União, Estado e Município ou para notificação do detentor de direitos.

Nessa fase o Oficial poderá realizar diligências, conforme dispõe o parágrafo $5^{\circ}$ do Art. 216-A da LRP, para sanar qualquer dúvida ou situação inerente ao procedimento. Poderá, ainda, promover notificações aos detentores de direitos averbados ou registrados na matrícula (ou em transcrição, sistema de registro anterior à Lei $n^{\circ}$ 6.015/73) do imóvel usucapiendo. Essas notificações podem ser feitas pessoalmente ou pelo correio com aviso de recebimento. Decorrido o prazo de 15 (quinze) dias e não havendo manifestação contrária de forma expressa, o silêncio será considerado como concordância.

Caso o imóvel pertença a condomínio edilício, basta anuência do síndico, conforme o disposto no parágrafo 11 do Art. 216-A da LRP. Se o confrontante for um condomínio, basta também anuência do síndico, conforme o disposto no parágrafo 12 do Art. 216-A da LRP (MOREIRA, 2016).

Se o Oficial não encontrar o notificando ou este encontrar-se em local incerto ou não sabido, o Oficial de registro certificará esta situação e promoverá a notificação por edital. O edital deverá ser publicado por duas vezes em jornal de grande circulação, num prazo de 15 (quinze) dias cada publicação. Considerando o silêncio como concordância. Se houver impugnação por parte do proprietário tabular, o Oficial poderá tentar conciliar às partes.

A Corregedoria Estadual de Justiça poderá autorizar a publicação de edital via meio eletrônico, dispensando a publicação em jornal de grande circulação, nos termos do parágrafo 14 do Art. 216-A da Lei $n^{\circ} 6.015 / 73$.

As procuradorias serão notificadas por correio com aviso de recebimento, conforme o parágrafo $3^{\circ}$ do Art. 216-A da LRP, que seguirá a mesma regra anterior no que diz respeito às anuências, com obediência ao prazo de 15 (quinze) dias, considerando o silêncio como concordância. 
Após essa fase de exame e superada todas essas particularidades, o resultado se dará da seguinte forma: se houver impugnação nos termos do Art. 18 do Provimento 65 do CNJ, a impugnação acarretará encaminhamento ao judiciário.

Cumpre ressaltar que não é permitido impugnação verbal. A impugnação deverá ser por escrito, fundamentada e protocolizada a tempo no cartório de Registro de Imóveis, se assim não for, esse prazo será considerado como expirado e seguirá para registro. Do contrário, terá que ser emendado e apresentado ao juízo competente da comarca de localização do imóvel usucapiendo para seguir o seu curso na via jurisdicional.

Havendo ausência de algum documento do inciso IV do Art. 216-A da LRP, haverá possibilidade de Audiência de Justificação Administrativa.

\subsection{Procedimento de justificação administrativa e de suscitação de dúvida}

O requerente está amparado por qualquer exigência arbitrária. No caso de o imóvel não ter registro ou de o requerente não possuir o justo título ou quaisquer outros documentos que demonstrem a origem, a continuidade, a natureza e o tempo da posse, e outros, como pagamentos de impostos ou taxas que incidirem sobre o imóvel.

Não dispondo o requerente desses documentos a medida legal cabível para sanar essas exigências quando forem os documentos ausentes ou insuficientes é o Procedimento de Justificação Administrativo, que é uma novidade trazida pela Lei n 13.465/17.

A finalidade da Justificação Administrativa é provar a posse e os demais dados necessários. 0 procedimento ocorrerá perante a serventia extrajudicial. O pedido deve conter a justificação e fundamentação da necessidade. É como uma audiência para a produção de prova. O rito seguirá os Arts. 382 e 383 do Novo Código de Processo Civil (NCPC).

Há, ainda, a possibilidade de requerer ao Oficial a Suscitação de Dúvida (Art. 204 da LRP), na qual, remeterá ao juiz competente a dúvida para ser sanada. O Procedimento de Suscitação de Dúvida no Registro de Imóveis seria uma medida recursal em face das famigeradas notas devolutivas, pois se no exame jurídico (qualificador) o Oficial de registro ou seu preposto verificar que o título não atende às exigências legais, constitui dever deste Oficial encaminhar o pedido para exigência, formulando assim as notas devolutivas. 
As notas devolutivas devem ser por escrito e fundamentada (legítima), ser razoável (próregistro), clara, objetiva e exaustiva (deve trazer todas às exigências de uma só vez).

Não se conformando o apresentante com a exigência do oficial ou não a podendo satisfazer, será o título, a seu requerimento e com a declaração de dúvida, remetido ao juiz competente para dirimi-la.

Dessa forma, a Suscitação de Dúvidas é uma medida recursal a ser adotada para casos de inconformidade com às exigências contidas em uma Nota Devolutiva, quando o interessado não concordar com às exigências formuladas pelo cartório ou quando não puder satisfazer às exigências de forma plena.

A Lei $n^{\circ}$ 6.015/73 (LRP) oportuniza que qualquer pessoa pode provocar o registro ou averbação de qualquer ato (Art. 217 LRP), em via de regra o Apresentante será a pessoa legitimada a requerer o procedimento de Suscitação de Dúvida.

Há a presunção de que o Apresentante represente os interesses daqueles que figuram como partes no título que se deseja registrar ou averbar. Todavia, o examinador do título no Cartório de Registro de Imóveis, de acordo com o caso concreto, poderá averiguar se o Apresentante realmente tem interesse que não vai contra dos que figuram no título.

Assim, o apresentante solicita a Suscitação de Dúvida, mas quem efetivamente a suscita é o próprio Oficial de Registro que peticiona ao juiz competente. Por exemplo, se o Oficial de Registro não remete a tempo o pedido de dúvida ou o Apresentante considera que às exigências não tem amparo legal, pode o próprio Apresentante suscitar a Dúvida Inversa.

A dúvida inversa difere-se da suscitação de dúvida apenas pelo fato de quem aciona o juiz é o próprio Apresentante do título a ser registrado/averbado. A dúvida inversa é admitida como medida de economia processual.

Os atos praticados no Registro de Imóveis que podem ser objeto de uma suscitação de dúvida são a averbação e o registro. A Averbação como já mencionado anteriormente é o ato que qualifica ou acrescenta informações sobre o imóvel ou aos detentores de direitos anteriormente averbados ou registrados na matrícula do imóvel; e o Registro é o ato que muda a titularidade do imóvel, seja de forma onerosa ou não. 
A Usucapião é hipótese de registro, porque muda a titularidade do imóvel, na qual há uma aquisição originária, pela prescrição aquisitiva dos titulares de direitos registrados ou averbados na matrícula do imóvel usucapiendo.

Se a dúvida for declarada pelo juiz competente procedente, os documentos são entregues ao Apresentante do título, independentemente de traslado, e é dada ciência ao Oficial de Registro, para que a consigne no protocolo e cancele a prenotação (Art. 203, I, da LRP).

Caso o juiz declare a improcedência, o Apresentante reapresentará o título e seus documentos, inclusos de mandado ou certidão da sentença, que ficarão arquivados, e o Oficial de Registro procederá com o registro/averbação desde logo, declarando tal fato na coluna de anotação do protocolo (Art. 203, II, da LRP).

Da sentença de suscitação de dúvida cabe apelação para o Conselho da Magistratura, nos efeitos devolutivo e suspensivo. Podendo ser interposta pelo interessado, Ministério Público ou por terceiro que venha a ser prejudicado da decisão. A decisão tem natureza administrativa e não impede ajuizamento de ação, de acordo com o disposto no Art. 202 da LRP.

\section{CONCLUSÃO}

A Usucapião Extrajudicial revela-se como o instituto de direito civil mais novo desjudicializado. É público e notório que o Judiciário brasileiro está sobrecarregado e que os processos judiciais tendem a se estender por vários anos.

O procedimento em âmbito cartorário requerido diretamente ao Oficial de Registro de Imóveis possibilita aos possuidores não proprietários a garantia da função social da posse. $O$ fato de o requerente poder buscar uma solução jurídica extrajudicialmente é uma inovação. Ao evitar a judicialização do pedido, torna-se mais um benefício da usucapião extrajudicial.

A proposta principal da usucapião é a proteção da função social da propriedade. Sabe-se que mesmo sendo uma garantia fundamental ao direito de propriedade constante no Art. $5^{\circ}$, inciso XXII da CRFB/88, esta não se mostra de forma absoluta.

O interessado e o advogado devem avaliar, no entanto, se será de fato possível a realização do procedimento extrajudicial, pois cada caso é um caso. No entanto, os ditames da justiça social, da 
existência digna de cada cidadão em saber que mora no que é seu, que tem a propriedade regularizada em seu nome, para poder usar, fruir, dispor a qualquer tempo, sem nenhum receio de perdê-la para quem injustamente a possua, hipótese que poderá reivindicar, é um direito fundamental inerente a todo brasileiro.

O enquadramento fático da posse ao preceito legal disciplinado pelo legislador, no direito material, possibilita aos possuidores não proprietário a aquisição da propriedade, tendo em vista o lapso temporal exigido por lei, à situação de posse, pois há 10 (dez) espécies ou modalidades de usucapião.

O imóvel legalizado tem um valor agregado de mercado de $30 \%$ a $40 \%$ com relação ao não legalizado. Dessa forma, o proprietário terá um ganho de capital muito bom em uma possível alienação do bem, pois a valorização é evidente.

O Poder Público, também será beneficiado com a regularização do imóvel, pois caso haja uma transação imobiliária de venda e compra, haverá a necessidade de realizar o pagamento do imposto de transmissão incidente.

Outro benefício inerente a legalização da propriedade seria o fato de não deixar para os sucessores do de cujus problemas jurídicos e financeiros. Em havendo herdeiros estes obterão a partilha do bem de maneira muito menos burocrática, com o fim de manter a estabilidade do direito e da paz social.

O direito processual da usucapião aplicado em âmbito cartorário, possibilita celeridade ao procedimento muito mais satisfatório do que aquele realizado em âmbito judicial.

O Registro de Imóvel ratificará a posse ao promover a chancela registral em prol do usucapiente que preencher os requisitos legais para a aquisição originária da propriedade, pela prescrição aquisitiva do proprietário tabular.

No procedimento extrajudicial de reconhecimento da usucapião não existe partes, mas sim interessados. A ideia de partes vem dos procedimentos judiciais. Já o pedido extrajudicial tem como fator preponderante a consensualidade. Assim, o interessado assistido por advogado procura o Registro de Imóvel competente e realiza o pedido de reconhecimento da usucapião.

Abre-se uma nova matrícula para o imóvel. Porquanto, no sistema atual de registro fala-se em fichas. O imóvel terá toda e completa especificação objetiva e subjetiva, na qual, proporcionará segurança jurídica em qualquer ato sobre o mesmo. Uma nova certidão estará atualizada. 
O Registrador não tem função de julgar, mas sim, de prestar um atendimento de qualidade pautado na lei, para a chancela registral. O Registrador deverá buscar o máximo de imparcialidade nos atos para que não beneficie nem prejudique o direito que o requerente tem de apreciação do pedido, e este por sua vez obterá uma apreciação do seu requerimento com toda credibilidade e confiabilidade concedida ao Registrador através da legitimação registral ou fé pública, pois o Oficial de Registro é um delegatório do Poder Público, sendo fiscalizado pelo mesmo.

Cabe ao Registrador analisar toda documentação, verificar se todos os requisitos exigidos se encontram preenchidos, com total independência para os seus atos. Caso entenda que há vícios impeditivos ao reconhecimento da usucapião extrajudicial, deverá emitir pareceres fundamentados. Esses pareceres são chamados de notas devolutivas que devem conter todas às exigências de uma só vez e, se possível, que sejam pró-registro evitando exigências infundadas e descabidas, a menos que realmente o requerente não preencha os requisitos exigidos por lei.

O requerente está amparado por qualquer exigência arbitrária, pois antes de haver rejeição do pedido extrajudicialmente, será oportunizado ao requerente recorrer ao Juiz Corregedor ou até mesmo ao Conselho da Magistratura para dirimir possíveis dúvidas que o registrador possa ter.

As repercussões sociais e econômicas da usucapião extrajudicial são extraordinárias. A possibilidade de acesso ao crédito com garantia real, a materialização dos conceitos constitucionais de função social da propriedade e de acesso à moradia, torna-se a usucapião extrajudicial uma das inovações mais importantes introduzidas com a vigência no Novo Código de Processo Civil, Lei $n^{\circ}$ $13.105 / 2015$.

Ao final, conclui-se que o pedido para o reconhecimento extrajudicial da usucapião é uma solução jurídica viável, célere e eficaz àqueles que buscam a regularização do imóvel usucapiendo.

\section{REFERÊNCIAS}

AGHIARIAN, Hércules. Curso de direito imobiliário. 12ª̣ed. São Paulo: Atlas, 2015.

ALVES, José Carlos Moreira. Direito Romano. 14a ed. Rio de Janeiro: Saraiva, 2007.

BOCZAR, Ana Clara Amaral Arantes e MACULAN, Letícia Franco Assumpção. Usucapião Extrajudicial: Questões Notariais e Tributárias. Leme (SP): JH Mizuno, 2018. 
BORGES, Antônio Moura. Registro de Imóveis Comentado. 4a ed. São Paulo: Contemplar, 2014.

BRASIL. Constituição da República Federativa do Brasil de 1988. Disponível em: www.planalto.gov.br. Acesso em: out. 2019.

BRASIL. Conselho Nacional de Justiça. Provimento 65 de 14 de dezembro de 2017. Estabelece as diretrizes para o procedimento de reconhecimento da usucapião extrajudicial. Disponível em: www.planalto.gov.br. Acesso em: jul. 2019.

BRASIL. Lei n 6.015, de 31 de dezembro de 1973. Lei de Registros Públicos. Brasília, DF, 31 dez. 1973. Disponível em:www.planalto.gov.br. Acesso em: set. 2018.

BRASIL. Lei n 13.105, de 16 de março de 2015. Código de Processo Civil. Brasília, DF, 16 mar. 2015. Disponível em:www.planalto.gov.br. Acesso em: ago. 2019.

CHAVES, Cristiano; ROSENVALD, Nelson. Curso de Direito Civil: Direitos Reais. $8^{a}$ ed. Salvador: Editora JusPodivm, 2012.

DINIZ, Maria Helena. Curso de direito civil brasileiro.Volume 6: direito das sucessões. 23a ed. Reformulada. São Paulo: Saraiva, 2009.

GONÇALVES, Carlos Roberto. Direito Civil Brasileiro.Volume 5: Direito das coisas. 10ạ ed. São Paulo: Saraiva, 2015.

MACULAN, Letícia Franco. A Usucapião Extrajudicial e o Provimento 65/CNJ. Brasília, 20 dez. 2017. Colégio Notarial do Brasil. Disponível em: www.notariado.org.br. Acesso em: ago. 2019.

MELLO, Henrique Ferraz Corrêa de. Usucapião Extrajudicial. São Paulo: YK Editora, 2016.

MOREIRA. Adriano Fernandes. O pedido de reconhecimento extrajudicial de usucapião no Cartório de Registro de Imóveis: análise dos artigos 1.071 do NCPC e 216-A da Lei de Registros Públicos. 1a ed. Gurupi:Célere, 2016.

NOBRE, Francisco José Barbosa. Manual da usucapião extrajudicial: de acordo com a Lei ${ }^{\circ}$ 13.465/2017, incluindo comentários ao Provimento ${ }^{\circ} 65 / 2017$ do CNJ. 1 a ed. Ananindeua: Itacaiúnas, 2018.

RIBEIRO, Benedito Silvério. Tratado de Usucapião. Volume 2. 8eed. São Paulo: Saraiva, 2012.

SARMENTO FILHO, Eduardo Sócrates Castanheira. Direito Registral Imobiliário: Teoria Geral, de acordo com o Novo Código de Processo Civil e a Lei 13.465/2017. 1a ed. Curitiba. Juruá Editora, 2017.

SERRA, Márcio Guerra e SERRA, Monete Hipólito. Registro de Imóveis I: parte geral. 3ạ ed. São Paulo: Saraiva Educação, 2018.

Trabalho recebido em 06 de setembro de 2019

Aceito em 12 de março de 2021 